\title{
ANALISIS FAKTOR-FAKTOR YANG BERPENGARUH TERHADAP PRODUKSI DAN PENDAPATAN PENGUSAHA INDUSTRI GENTENG
}

\author{
I Made Bayu Wira Satya Susila Putra ${ }^{1}$ \\ I Nyoman Mahaendra Yasa² \\ ${ }^{1,2}$ Fakultas Ekonomi dan Bisnis Universitas Udayana (Unud), Bali, Indonesia \\ E-mail: bayusatya07@gmail.com
}

\begin{abstract}
Analysis of the Influential Factors on the Production and Income of Roof Tile Entrepreneurs. The purpose of this study is to determine the effect of labor and capital on income through production. The analysis technique used in this study is path analysis. The results showed that labor and capital directly had a positive and significant effect on production, and also labor, capital and production directly had a positive and significant effect on the income of tile industry entrepreneurs. The sobel test results show that labor and capital indirectly affect income through production. It is hoped that entrepreneurs can improve the quality of the workforce with the latest production methods by using the latest technology and can add workforce in the field of marketing and financial management, and also increase capital for optimal raw material purchases and to increase competitiveness. Entrepreneurs can increase production by marketing it through digital media such as social media and e-commerce that can increase revenue optimally.
\end{abstract}

Keywords: labor, capital, production, income, industry

\begin{abstract}
Abstrak: Analisis Faktor-Faktor yang Berpengaruh Terhadap Produksi dan Pendapatan Pengusaha Industri Genteng. Tujuan dari penelitian ini adalah untuk mengetahui pengaruh tenaga kerja dan modal terhadap pendapatan melalui produksi. Teknik analisis yang digunakan dalam penelitian ini adalah analisis jalur (path analysis).Hasil penelitian menunjukkan bahwa tenaga kerja dan modal secara langsung berpengaruh positif dan signifikan terhadap produksi, dan juga tenaga kerja, modal dan produksi secara langsung berpengaruh positif dan signifikan terhadap pendapatan pengusaha industri genteng. Hasil uji sobel menunjukkan tenaga kerja dan modal secara tidak langsung berpengaruh terhadap pendapatan melalui produksi. Diharapkan pengusaha dapat meningkatkan kualitas tenaga kerja dengan metode produksi terbaru dengan menggunakan teknologi terkini dan dapat menambah tenaga kerja dibidang pemasaran dan pengelolaan keuangan, dan juga menambah modalnya untuk pembelian bahan baku yang optimal dan untuk meningkatkan daya saing. Pengusaha dapat meningkatkan produksinya dengab cara memasarkannya melalui media digital seperti media sosial dan e-commerce yang dapat meningkatakan pendapatan secara optimal.
\end{abstract}

Kata kunci: tenaga kerja, modal, produksi, pendapatan, industri 


\section{PENDAHULUAN}

Keberadaan industri kecil memiliki peranan yang penting. Industri kecil umumnya berkembang karena adanya semangat kewirausahaan lokal. Aktivitas ekonomi industri kecil lebih mengutamakan pemanfaatan sumber daya lokal, terutama input bahan baku dan tenaga kerjanya.Dalam proses pembangunan selalu diupayakan pertumbuhan ekonomi adalah setinggi mungkin (Rimbawan, 2012). Perkembangan industri pada masing-masing negara berada pada tahap yang berbeda-beda namun semua negara memandang industri sebagai bagian penting untuk meningkatkan perekonomian (Shanmugasundaram, 2011).

Pertumbuhan sektor - sektor ekonomi di Indonesia berkembang pesat, salah satu yang terjadi di sektor industri. Pertumbuhan sektor industri di Indonesia akan sangat dipengaruhi oleh skala produksi atau skala usaha dari suatu perusahaan yang masuk dalam industri tersebut, dan biasanya semakin besar skala usaha produksinya cenderung akan menunjukan tingkat efisiensi penggunaan faktor - faktor produksi atau input yang tinggi sehingga perusahaan akan berkembang pesat (Indra, 2015). Pembangunan sektor Industri memiliki keuntungan yang berlimpah untuk ekonomi lokal, dan berkontribusi terhadap Produk Domestik Bruto (PDB), pendapatan devisa danlapangankerja.Pembangunan sektor industri dengan melakukan pengelompokan suatu perusahaan dapat memberikan dampak pada efisiensi dan pertumbuhan produktivitas (Widodo, 2014). Pembangunan ekonomi dan industri mampu memberikan kemajuan baru pada negara berkembang (Ofuri, 2006). Pembangunan industri merupakan suatu kegiatan yang mempunyai potensi untuk dikembangkan mengingat sumber daya alam lokal dan kreativitas masyarakat pada bidang seni maupun kerajinan cukup memberikan kontribusi pada peningkatan kesejahteraan masyarakat untuk lebih maju dan bermutu (Budiartha, 2013).

Perkembangan yang terjadi di sektor industri sekarang ini baik sektor industri besar, kecil, menengah, dan rumah tangga mulai menjadikan sektor industri sebagai sektor yang sangat diminati dan bisa berkembang dengan pesat apalagi didukung dengan penerapan teknologi yang juga terus mengalami perkembangan seperti menggunakan peralatan dan mesin untuk produksi barang dan jasa (Obioma, 2015). Sektor industri pengolahan dalam prosesnya telah memberikan sumbangan bagi Produk Domestik Regional Bruto (Cahya, 2015).

Bali merupakan salah satu provinsi di Indonesia yang memiliki karakteristik perekonomian yang sangat spesifik bila dibandingkan dengan Provinsi lainnya di Indonesia apabila dilihat dari faktor - faktor seperti pesona alam, seni, budaya, dan adat istiadat yang sudah terkenal di manca negara. Hal inilah yang berperan dalam meningkatkan Produk Domestik Regional Bruto (PDRB) Provinsi Bali di masing-masing sektor (Wijaya, 2016).

Jumlah PDRB Provinsi Bali dari tahun 2013 sampai tahun 2017, dapat di lihat bahwa sektor industri pengolahan di Provinsi Bali setiap tahunnya mengalami tren peningkatan. Menurut Rahmaddi (2013), meningkatnya ekspor pada industri pengolahan yang terus berlanjut diakibatkan karena Indonesia mendapatkan peningkatan investasi dari negara lain. Hal ini berarti Bali memiliki sektor industri yang cukup menjanjikan dan mampu berkembang dengan baik. Berikut ini adalah persentase distribusi PDRB sektor industri pengolahan menurut kabupaten/kota di Provinsi Bali dapat dilihat pada Tabel 1.

Berdasarkan Tabel 1, di Kabupaten Tabanan distribusi PDRB sektor industri pengolahannya mengalami tren yang positif dimana sepanjang tahun 2013-2017 Kabupaten Tabanan terus mengalami peningkatan setiap tahunnya dibandingkan kabupaten lainnya. Di Kabupaten Tabanan juga industri pengolahan dari subsektor pengolahan genteng adalah industri pengolahan genteng terbanyak di bandingkan kabupaten/kota di Provinsi Bali. Berikut ini adalah jumlah usaha, tenaga kerja dan nilai produksi pada industri genteng masing-masing Kabupaten/Kota Provinsi Bali tahun 2017 yang dapat di lihat pada Tabel 2. 
Tabel 1.

Distribusi PDRB Sektor Industri Pengolahan Menurut Kabupaten/Kota di Provinsi Bali Tahun 2013-2017 ( dalam \%)

\begin{tabular}{lrrrrr}
\hline Kabupaten/kota & $\mathbf{2 0 1 3}$ & $\mathbf{2 0 1 4}$ & $\mathbf{2 0 1 5}$ & $\mathbf{2 0 1 6}$ & $\mathbf{2 0 1 7}$ \\
\hline Jembrana & 4,90 & 4,90 & 4,99 & 4,99 & 4,87 \\
Tabanan & $\mathbf{5 , 6 5}$ & $\mathbf{5 , 6 5}$ & $\mathbf{5 , 6 7}$ & $\mathbf{5 , 9 7}$ & $\mathbf{6 , 2 5}$ \\
Badung & 4,21 & 3,99 & 4,08 & 3,99 & 3,73 \\
Gianyar & 12,10 & 12,11 & 12,16 & 12,47 & 12,32 \\
Klungkung & 9,00 & 9,10 & 9,30 & 9,45 & 9,33 \\
Bangli & 9,48 & 9,55 & 9,87 & 9,80 & 9,28 \\
Karangasem & 4,04 & 4,01 & 4,13 & 4,08 & 3,98 \\
Buleleng & 5,79 & 5,87 & 6,09 & 5,99 & 5,86 \\
Denpasar & 7,01 & 6,85 & 6,75 & 6,57 & 6,35 \\
Provinsi Bali & 6,90 & 6,89 & 7,00 & 7,03 & 6,88 \\
\hline
\end{tabular}

Sumber:Badan Pusat Statistik Provinsi Bali, 2018

Tabel 2.

Jumlah Usaha, Tenaga Kerja Serta Nilai Produksi pada Industri GentengMenurut Kabupaten/ Kota di Provinsi Bali Tahun 2017

\begin{tabular}{lccc}
\hline Kabupaten / kota & $\begin{array}{c}\text { Jumlah Usaha } \\
\text { (Unit) }\end{array}$ & $\begin{array}{c}\text { Tenaga Kerja } \\
\text { (Orang) }\end{array}$ & $\begin{array}{c}\text { Nilai Produksi } \\
\text { (Rp.) }\end{array}$ \\
\hline Denpasar & 2 & 14 & 28.800 .000 \\
Klungkung & 2 & 18 & 27.500 .000 \\
Badung & 8 & 117 & 3.505 .868 .000 \\
Buleleng & 2 & 9 & 54.180 .000 \\
Gianyar & 0 & 0 & 0 \\
Jembrana & 10 & 71 & 4.767 .000 .000 \\
Karangasem & 0 & 0 & 0 \\
Tabanan & $\mathbf{6 5}$ & $\mathbf{3 6 6}$ & $\mathbf{1 2 . 4 1 8 . 4 8 5 . 0 0 0}$ \\
Bangli & 0 & 0 & 0 \\
Provinsi Bali & 89 & \multicolumn{5}{c}{595} & 20.801 .833 .000 \\
\hline Sumber:Dinas Perindustrian dan Perdagangan Provinsi Bali, 2018
\end{tabular}

Berdasarkan Tabel 2 dapat dilihat Kabupaten Tabanan memiliki jumlah unit usaha, tenaga kerja dan nilai produksi yang terbanyak dan tertinggi pada industri genteng di bandingkan dengan kabupaten / kota yang ada di Provinsi Bali. Atas dasar inilah yang menjadi alasan memilih industri genteng di Kabupaten Tabanan sebagai tempat penelitian.

Pembangunan industri kecil di Kabupaten Tabanan sangat memiliki potensi untukdikembangkan, mengingat sumber daya alam dan kreativitas dari masyarakat yang cukup memberikan kontribusi pada peningkatan kesejahteraan masyarakat yang mendukung pembangunan daerah. Sektor industrisangatpentinguntukpenyerapantenaga kerja dan membantu dalam perekonomian masyarakatsetempat. Perkembangan industri di berbagaisektor memiliki dampak yang positif terhadap pertumbuhan industri yang dapat membuka lapangan pekerjaan (Marbek, 2013). Berikut ini adalah jumlah usaha, tenaga kerja dan nilai produksi pada industri kecil masing-masing kecamatan di Kabupaten Tabanan tahun 2017 yang dapat di lihat pada Tabel 3.

Berdasarkan Tabel 3 keberadaan industri kecil yang terdiri dari jumlah unit usaha sebanyak 878 unit, tenaga kerja yang terserap sebanyak 7.600 orang, dan total nilai 
Tabel 3.

Industri Kecil Menurut Jumlah Unit Usaha, Nilai Produksi, dan Tenaga Kerja Menurut Kecamatan / Kota di Kabupaten Tabanan Tahun 2017

\begin{tabular}{llccc}
\hline No & \multicolumn{1}{c}{ Kecamatan } & $\begin{array}{c}\text { Jumlah Usaha } \\
\text { (unit) }\end{array}$ & $\begin{array}{c}\text { Total Nilai Produksi } \\
\text { (Rp.) }\end{array}$ & $\begin{array}{c}\text { Total Tenaga } \\
\text { Kerja (orang) }\end{array}$ \\
\hline 1 & Baturiti & 46 & 35.169 .702 .000 & 369 \\
2 & Kediri & 214 & 124.147 .910 .000 & 1.841 \\
3 & Kerambitan & 78 & 73.859 .800 .000 & 1.107 \\
4 & Marga & 102 & 52.763 .930 .000 & 620 \\
5 & Penebel & 82 & 67.937 .891 .000 & 484 \\
6 & Pupuan & 39 & 29.614 .400 .000 & 297 \\
7 & Selemadeg & 40 & 26.798 .400 .000 & 267 \\
8 & Selemadeg Timur & 56 & 25.672 .100 .000 & 380 \\
9 & Selemadeg Barat & 25 & 9.372 .000 .000 & 160 \\
10 & Tabanan & 196 & 121.720 .197 .000 & 2.075 \\
& Kabupaten Tabanan & $\mathbf{8 7 8}$ & $\mathbf{5 6 7 . 0 5 6 . 3 3 0 . 0 0 0}$ & $\mathbf{7 . 6 0 0}$ \\
\hline
\end{tabular}

Sumber:Dinas Perindustrian dan Perdagangan Kabupaten Tabanan, 2018

Tabel 4.

Jumlah 5 (Lima) Besar Industri Kecil Menurut Kecamatan di KabupatenTabanan

Tahun 2017 (unit)

\begin{tabular}{llrrrrr}
\hline No & Kecamatan & $\begin{array}{c}\text { Industri } \\
\text { Kayu }\end{array}$ & $\begin{array}{c}\text { Industri } \\
\text { Genteng }\end{array}$ & $\begin{array}{c}\text { Industri } \\
\text { Ukiran } \\
\text { Kayu }\end{array}$ & $\begin{array}{c}\text { Imdustri } \\
\text { Barang dari } \\
\text { Semen }\end{array}$ & $\begin{array}{c}\text { Industri } \\
\text { Pakaian } \\
\text { jadi }\end{array}$ \\
\hline 1 & Baturuti & 14 & 0 & 4 & 4 & 0 \\
2 & Kediri & 16 & 65 & 4 & 10 & 16 \\
3 & Kerambitan & 11 & 0 & 9 & 7 & 4 \\
4 & Marga & 23 & 0 & 23 & 10 & 1 \\
5 & Penebel & 26 & 0 & 7 & 3 & 3 \\
6 & Pupuan & 13 & 0 & 1 & 2 & 0 \\
7 & Selemadeg & 15 & 0 & 3 & 1 & 0 \\
8 & Selemadeg Timur & 19 & 0 & 3 & 3 & 1 \\
9 & Selemadeg Barat & 9 & 0 & 0 & 2 & 0 \\
10 & Tabanan & 15 & 0 & 7 & 5 & 16 \\
\hline & Kabupaten Tabanan & $\mathbf{1 6 1}$ & $\mathbf{6 5}$ & $\mathbf{6 1}$ & $\mathbf{4 7}$ & $\mathbf{4 1}$ \\
\hline
\end{tabular}

Sumber : Dinas Perindustrian dan Perdagangan Kabupaten Tabanan, 2018

produksi mencapai $\mathrm{Rp}$ 567.056.330.000. Terlihat bahwa Kecamatan Kediri merupakan kecamatan yang memiliki perkembangan industri kecil paling banyak di Kabupaten Tabanan dengan 214 unit usaha dengan tenaga kerja 1.841 dan dengan nilai produksi $\mathrm{Rp}$ 124.147.910.000. Dan juga sektor industri genteng di Kecamatan Kediri merupakan salah satu industri kecil yang berpengaruh diantara kecamatan lainnya yang ada di Kabupaten Tabanan. Berikut ini jumlah lima besar industri kecil menengah setiap kecamatan di Kabupaten Tabanan pada Tabel 4.

Berdasarkan Tabel 4, yang merupakan lima besar industri kecil yang paling banyak berkembang di Kabupaten yaitu industri genteng dari Kecamatan Kediri. Untuk jumlah unit usaha, tenaga kerja dan nilai produksi industri genteng yang berada di Kecamatan Kediri Kabupaten Tabanan dapat di lihat pada Tabel 5.

Tabel 5 menunjukkan perkembangan 
Tabel 5.

Jumlah Unit Usaha, Tenaga Kerja dan Nilai Produksi Industri Genteng diKecamatan Kediri, Kabupaten Tabanan Tahun 2013 - 2017

\begin{tabular}{cccc}
\hline Tahun & $\begin{array}{c}\text { Jumlah Usaha } \\
\text { (unit) }\end{array}$ & $\begin{array}{c}\text { Jumlah Tenaga Kerja } \\
\text { (orang) }\end{array}$ & $\begin{array}{c}\text { Jumlah Nilai Produksi } \\
\text { (Rp.) }\end{array}$ \\
\hline 2013 & 55 & 379 & 11.511 .345 .000 \\
2014 & 70 & 462 & 14.062 .685 .000 \\
2015 & 62 & 364 & 12.080 .885 .000 \\
2016 & 63 & 369 & 12.019 .485 .000 \\
2017 & 65 & 366 & 12.418 .485 .000 \\
\hline
\end{tabular}

Sumber:Dinas Perindustrian dan Perdagangan Kabupaten Tabanan, 2018

Tabel 6.

Jumlah Industri Genteng Menurut Desa di Kecamatan Kediri Kabupaten Tabanan

Tahun 2017

\begin{tabular}{clcc}
\hline No & \multicolumn{1}{c}{ Desa } & Jumlah Usaha (unit) & Tenaga Kerja (orang) \\
\hline 1 & Pejaten & 23 & 128 \\
2 & Nyitdah & 42 & 238 \\
& Kecamatan Kediri & $\mathbf{6 5}$ & $\mathbf{3 6 6}$ \\
\hline
\end{tabular}

Sumber:Dinas Perindustrian dan Perdagangan Kabupaten Tabanan, 2018

industri genteng di Kecamatan Kediri, Kabupaten Tabanan selama lima tahun terlihat jelas bahwa jumlah unit usaha, tenaga kerja dan nilai produksi industri genteng mengalami pertumbuhan yang berfluktuatif. pada tahun 2014 jumlah unit usaha, tenaga kerja, dan nilai produksi industri genteng mengalami peningkatan, namun pada tahun 2015 unit usaha dan tenaga kerja kembali mengalami penurunan begitu pula dengan nilai produksinya yang menurun sebesar Rp. 2.551,307. Pada tahun 2016 jumlah unit usaha dan tenaga kerja industri genteng kembali meningkat sebanyak satu unit usaha dan penambahan tenaga kerja sebanyak 5 orang. Terlihat pada tahun 2017 , pertumbuhan unit usaha dan pertumbuhan nilai produksi mengalami peningkatan tetapi tidak dengan tenaga kerja yang mengalami penurunan sebanyak 3 orang.

Desa Pejaten dan Desa Nyitdah merupakan desa yang terdapat di Kecamatan Kediri Kabupaten Tabanan yang merupakan desa yang di kenal sebagai desa penghasil genteng. Industri genteng di Desa Pejaten dan Desa Nyitdah merupakan industri non formal yang memiliki jumlah unit usaha yang cukup banyak dan mampu menyerap tenaga kerja. Berikut ini adalah jumlah usaha dan tenaga kerja menurut Desa di Kecamatan Kediri pada Tabel 6.

Tabel 6 memberikan informasi tentang keberadaan industri genteng di Kecamatan Kediri Kabupaten Tabanan yang berjumlah 65 unit usaha dengan jumlah tenaga kerja sebanyak 366 orang, dimana Desa Nyitdah merupakan desa yang memiliki industri genteng paling banyak dari Desa Pejaten. Walaupun begitu dalam masyarakat lebih terkenal Desa pejaten sebagai desa yang memproduksi genteng di bandingkan Desa Nyitdah, ini dikarenakan di Desa Pejaten lebih dulu masyarakatanya berusaha industri genteng dari pada Desa Nyitdah.

Secara umum, permasalahan yang dihadapi oleh pengusaha industri kecil adalah minimnya modal kerja dan atau modal investasi, kesulitan pemenuhan bahan baku dalam jangka panjang, keterbatasan teknologi, sumberdaya manusia dengan kualitas yang baik (terutama berkaitan dengan manajemen dan teknis produksi), informasi mengenai pasar dan tren, serta kesulitan dalam memasarkan produk yang dihasilkan (Tambunan, 2002:69). Permasalahan ini juga dihadapi oleh sebagian besar pengusaha industri kecil di Tabanan. Masalah eksternal meliputi rendahnya responsivitas terhadap 
iklim usaha yang semakin kondusif dan persaingan yang semakin ketat, koordinasi dan sinkronisasi pembinaan industri kecil yang mengalami perubahan terkait dengan masalah kelembagaan kekurangan sosialisasi mengenai prosedur perijinan, serta fasilitas lainnya yang mampu mendorong perkembangan industri kecil berupa perangkat hukum yang jelas, skema kredit serta pengawasan evaluasi.

Setiap industri memiliki karakteristik yang khusus dalam mempengaruhi perubahan nilai produksi (Ovtchinnikov,2010). Produksi merupakan aktivitas yang memproses bahan mentah menjadi produk jadi untuk memenuhi kebutuhan manusia dengan menghubungkan faktor input dan output (Gupta, 2016). Dalam proses produksi, faktor-faktor produksi harus dikombinasikan karena antara faktor produksi yang satu dengan yang lainnya tidak dapat berdiri sendiri. Faktor-faktor produksi dan pendapatan yang mempengaruhi berkembangnya suatu industri antara lain modal, tenaga kerja, bahan baku, transportasi, sumber energi atau bahan bakar dan pemasaran (Budiman, 2015).

Faktor tenaga kerja merupakan salah satu faktor yang memegang peranan penting dalam kegiatan produksi. Tenaga kerja berperan di dalam industri kecil yang bersifat umum, dimana ketelitian dan keterampilan dari karyawan yang menangani proses produksi mempunyai akibat langsung terhadap produksi yang dihasilkan (Wulandari dkk, 2016). Penggunaan tenaga kerja dengan kualitas dan jumlah yang sesuai memiliki pengaruh positif terhadap produksi usaha. Hal ini sesuai dengan hasil penelitian (Aldida,2013) yang mengatakan tenaga kerja memiliki pengaruh positif terhadap produksi industri.

Merujuk pada permasalahan yang ditunjukkan pada Tabel5, di mana pada tahum 2013 - 2014 mengalami peningkatan dan setahun setelahnya cenderung menurunnya nilai produksi industri genteng periode tahun 2015 hingga tahun 2016, ini menandakan kemungkinan besar penyebab nilai produksi industri genteng di Kabupaten Tabanan cenderung mengalami penurunan adalah kolaborasi antara penggunaan input yang tidak dikelola secara efisien mengakibatkan produk yang dihasilkan tidak optimal dan jika tidak segera diatasi akan dapat menyebabkan kekurangan ataupun pemborosan faktor produksi yang akan membuat industri tidak hanya mudah didirikan tetapi juga mudah menghilang dari peredaran dunia usaha. Salah satu cara yang dapat dilakukan adalah dengan mengkombinasikan dan memanfaatkan penggunaan faktor-faktor produksi secara proporsional mencapai kondisi efisien sehingga usaha genteng yang dijalankan dapat memberikan keuntungan yang maksimal. Efisieinsi diperlukan agar pengusaha mendapatkan kombinasi dari penggunaan faktor-faktor produksi tertentu untuk menghasilkan output yang maksimal dengan meminimalkan biaya faktor produksi (Ramstetter, 2014).

Hubungan antara tenaga kerja dengan produksi adalah pengaruh yang tidak pernah terjadi perpisahan karena semua produksi membutuhkan tenaga kerja untuk memperoleh suatu barang atau jasa. hal ini sejalan dengan Sukirno (2000:69), bahwa permintaan atas tenaga kerja merupakan permintaan tidak langsung, maksudnya tenaga kerja dipekerjakan oleh perusahaan dengan tujuan untuk digunakan dalam menghasilkan barang-barang yang mereka jual. Selanjutnya penelitian yang dilakukan oleh Wulandari dkk(2016),juga yang menyatakan bahwa tenaga kerja berpengaruh positif dan signifikan terhadap produksi industri perhiasan logam mulia di Kota Denpasar dengan asumsi bahwa variabel yang lain tetap. Tenaga kerja merupakan faktor-faktor produksi yang memiliki peran penting dalam proses produksi. Tanpa adanya tenaga kerja yang mengolah maka tidak akan ada produk yang dihasilkan untuk memenuhi permintaan konsumen. Dalam penelitian Ariessi (2017), variabel Tenaga Kerja berpengaruh positif dan signifikan terhadap Produktivitas Petani di Kecamatan Sukawati.

Tenaga kerja merupakan faktor yang sangat penting dalam produksi, karena tenaga kerja merupakan faktor penggerak faktor input yang lain, tanpa adanya tenaga kerja 
maka faktor produksi lain tidak akan berarti. Menurut Mankiwet al (2011), semakin banyak tenaga kerja maka semakin banyak pula output yang diproduksi, begitu pula sebaliknya. Menurut Sumarsono (2009), apabila banyak produk yang terjual sehingga dengan demikian pengusaha akan meningkatkan jumlah produksinya. Meningkatnya jumlah produksi akan mengakibatkan meningkatnya tenaga kerja yang dibutuhkan, sehingga dengan demikian pendapatan juga akan meningkat. Menurut hasil penelitian yang dilakukan oleh Adi(2016), menyatakan bahwa tenaga kerja mempunyai pengaruh yang positif dan signifikan terhadap jumlah pendapatan pada pedagang kaki lima di Kecamatan Denpasar Barat. Ng'ombe et al (2015), menyatakan tenaga kerja merupakan faktor produksi yang paling berpengaruh terhadap hasil produksi. Hoet al (2014) mengemukakan bahwa faktor produksi tenaga kerja berpengaruh signifikan terhadap hasil produksi.

Modal sangat berpengaruh positif terhadap tingkat produksi. Penelitian yang dilakukan Huazhang (2014), menyatakan bahwa modal berpengaruh positif terhadap hasil produksi. Jumlah modal yang tersedia bisa memenuhi seluruh kebutuhan produksi dalam perusahaan, maka proses produksi dengan lancar dan akan berpengaruh terhadap peningkatan jumlah hasil produksi. Penggunaan modal yang sangat besar dapat berpengaruh dapa peningkatan keuntungan yang diterima, sebaliknya jika modal yang dikeluarkan oleh perusahaan kecil akan berpengaruh pada keuntungan yang dihasilkan perusahaan. Modal merupakan titik kunci dari setiap industri dimana modal yang besar akan berpengaruh terhadap besarnya usaha (Dwi \& Jember, 2016)

Menurut Firdausa (2013), Modal merupakan salah satu inputatau faktor produksi yang dapat menentukan tinggi rendahnya pendapatan tetapi bukan berarti satu-satunya faktor yang dapat meningkatkan pendapatan. Menurut Youriyah (2007), dalam penelitiannya modal memiliki pengaruh yang signifikan terhadap pendapatan. Sehingga dalam hal ini modal bagi pengusaha juga merupakan salah satu faktor produksi yang mempengaruhi tingkat pendapatan. Hal ini sesuai dengan teori Cobb-Douglas yang menyatakan bahwa modal mempengaruhi output produksi. Hal ini menunjukkan semakin tinggi modal akan dapat meningkatkan hasil produksi, hal ini karena dalam proses produksi membutuhkan biaya yang di gunakan untuk pekerja dan pembelian bahan baku serta peralatan (Sulistiana, 2013). Modal yang dikeluarkan akan mempengaruhi besar pendapatan yang akan diterima (Putri, 2016).

Modal kerja merupakan suatu kebutuhan yang terus-menerus menentukan perkembangan suatu usaha yang menjadi penghubung alat, bahan dan jasa yang digunakan untuk proses produksi sehingga akan memperoleh penerimaan atau hasil penjualan (Ahmad, 2004 : 72).

Tingkat produksi akan mempengaruhi tingkat pendapatan yang di peroleh oleh pengrajin pada industri genteng. Ketika produksi yang dihasilkan menurun maka pendapatan yang diterima pengerajin akan mengalami penurunan. Dalam penelitian Prasetyo (2017), variabel tenaga kerja dan modal secara masing-masing atau parsial berpengaruh positif dan signifikan terhadap produksi.

\section{METODE PENELITIAN}

Lokasi penelitian ini dilakukan di Kecamatam Kediri, Kabupaten Tabanan, pemilihan ini di dasarkan karena di Kabupaten Tabanan merupakan kabupaten yang memiliki industri genteng terbanyak diantara kabupaten/ kota di Provinsi Bali. Selain itu daerah Desa Nyitdah dan Desa Pejaten merupakan daerah yang memiliki jumlah industri genteng terbanyak di Kecamatan Kediri, Kabupaten Tabanan.

Populasi yang digunakan peneliti dalam penelitian ini ialah 65 pengusaha industri genteng di Kecamatan Kediri, Kabupaten Tabanan. Dalam penelitian ini sampel Pengambilan sampel dalam penelitian ini dengan teknik Probability sampling yaitu proportionate stratified random sampling dengan menggunakan rumus slovin. Besarnya 
sampel dalam penelitian ini ditentukan dengan rumus Slovin sebagai berikut:

$$
n=\frac{N}{1+N e^{2}}
$$

Dimana :

$\mathrm{n}=$ jumlah elemen / anggota sampel

$\mathrm{N}$ = jumlah elemen / anggota populasi

$\mathrm{e}=$ error level (tingkat kesalahan) (catatan:

umumnya digunakan $1 \%$ atau $0,01,5 \%$ atau

0,05 , dan $10 \%$ atau 0,1 ) (catatan dapat dipilih oleh peneliti).

Populasi yang terdapat dari penelitian ini adalah 65 pengusaha industri genteng dan presisi yang ditetapkan atau tingkat signifikansi 0,1 , maka besarnya sampel pada penelitian ini adalah :

$$
\begin{aligned}
n & =\frac{N}{1+N e^{2}} \\
n & =\frac{65}{1+65 \cdot 0,1^{2}} \\
& =39,3 \\
& =39 \text { (di bulatkan) }
\end{aligned}
$$

$$
\begin{array}{rlrl}
\mathrm{n} & =\frac{23}{65} \times 39 & \mathrm{n} & =\frac{42}{65} \times 39 \\
& =14(\text { Desa Pejaten }) & =25(\text { Desa Nyitdah })
\end{array}
$$

Jadi, jumlah keseluruhan responden dalam penelitian ini adalah 39 pengusaha industri genteng di mana 14 di Desa Pejaten dan 25 di Desa Nyitdah. Seperti yang terdapat pada Tabel 7.

Teknik analisis data yang digunakan untuk memecahkan permasalahan dalam penelitian ini adalah teknik analisis jalur dengan menggunakan program SPSS.Maka persamaan regresinya yaitu sebagai berikut:

$\mathrm{Y}_{1}=\beta_{1} \mathrm{X}_{1}+\beta_{2} \mathrm{X}_{2}+\mathrm{e}_{1}$

$Y_{2}=\beta_{3} X_{1}+\beta_{4} X_{2}+\beta_{5} Y_{1}+e_{2}$

Keterangan:

$\mathrm{Y}_{1}=$ Produksi

$\mathrm{Y}_{2}=$ Pendapatan

$\mathrm{X}_{1}=$ Tenaga kerja

$\mathrm{X}_{2}=$ Modal

$\beta_{1} \ldots \beta_{5}=$ Koefisien regresi untuk masingmasing variabel

$\mathrm{e}_{1}, \mathrm{e}_{2}=$ error

\section{HASIL DAN PEMBAHASAN}

Pengujian persamaan 1 dilakukan untuk melihat pengaruh tenaga kerja dan modal terhadap produksi secara langsung yang dilakukan dengan menggunakan program SPSS Versi 20.0 maka uji regresi disajikan dalam Tabel 8 . Tabel 8 menunjukan hasil regresi tenaga kerja dan modal terhadap produksi.

Berdasarkan Tabel 8 tenaga Kerja dengan nilai sig $0,001<0,05$ dan beta 0,596

Tabel 7.

Jumlah Populasi dan Sampel Pengusaha Industri Genteng Menurut Desa di Kecamatan Kediri Kabupaten Tabanan Tahun 2017 (orang)

\begin{tabular}{clcc}
\hline No & \multicolumn{1}{c}{ Desa } & Populasi & Sampel \\
\hline 1 & Pejaten & 23 & 14 \\
2 & Nyitdah & 42 & 25 \\
& Kecamatan Kediri & $\mathbf{6 5}$ & $\mathbf{3 9}$ \\
\hline
\end{tabular}

Sumber:Data Diolah, 2019

Tabel 8.

Hasil Uji RegresiI Tenaga Kerja dan Modal terhadap Produksi

\section{Coefficients $^{\mathrm{a}}$}

\begin{tabular}{llrrrrr} 
& \multicolumn{7}{c}{ Standardized } \\
Model & \multicolumn{1}{c}{ Unstandardized Coefficients } & $\begin{array}{c}\text { Coefficients } \\
\text { B }\end{array}$ & Std. Error & Beta & \multicolumn{1}{c}{ T } & \multicolumn{1}{c}{ Sig. } \\
\hline 1 & (Constant) & 3595.019 & 1916.919 & & 1.875 & .069 \\
& Tenaga Kerja & 948.895 & 252.837 & .596 & 3.753 & .001 \\
& Modal & .001 & .000 & .384 & 2.420 & .021 \\
\hline
\end{tabular}


Tabel 9.

Hasil Uji Regresi II Tenaga Kerja, Modal dan Produksi terhadap Pendapatan

\section{Coefficients $^{\mathrm{a}}$}

\begin{tabular}{|c|c|c|c|c|c|c|}
\hline \multirow{2}{*}{\multicolumn{2}{|c|}{ Model }} & \multicolumn{2}{|c|}{ Unstandardized Coefficients } & \multicolumn{2}{|l|}{$\begin{array}{c}\text { Standardized } \\
\text { Coefficients }\end{array}$} & \multirow[b]{2}{*}{ Sig. } \\
\hline & & B & Std. Error & Beta & $\mathbf{t}$ & \\
\hline \multirow[t]{4}{*}{1} & (Constant) & -2812107.205 & 995009.968 & & -2.826 & .008 \\
\hline & Tenaga Kerja & 307465.244 & 147749.136 & .325 & 2.081 & .045 \\
\hline & Modal & .247 & .111 & .318 & 2.229 & .032 \\
\hline & Produksi & 208.099 & 82.572 & .350 & 2.520 & .016 \\
\hline
\end{tabular}

Tabel 10.

Ringkasan Koefisien Jalur

\begin{tabular}{lcrrrl}
\hline Regresi & $\begin{array}{c}\text { Koefisien Regresi } \\
\text { standar }\end{array}$ & $\begin{array}{c}\text { Standar } \\
\text { Error }\end{array}$ & T-hitung & Sig & Keterangan \\
\hline $\mathrm{X} 1 \longrightarrow \mathrm{Y} 1$ & 0,596 & 252,837 & 3,753 & 0,001 & Positif dan Signifikan \\
$\mathrm{X} 2 \longrightarrow \mathrm{Y} 1$ & 0,384 & 0,000 & 2,420 & 0,021 & Positif dan Signifikan \\
$\mathrm{X} 1 \longrightarrow \mathrm{Y} 2$ & 0,325 & 307465,244 & 2,081 & 0,045 & Positif dan Signifikan \\
$\mathrm{X} 2 \longrightarrow \mathrm{Y} 2$ & 0318 & 0,247 & 2,229 & 0,032 & Positif dan Signifikan \\
$\mathrm{Y} 1 \longrightarrow \mathrm{Y} 2$ & 0,350 & 208,099 & 2,520 & 0,016 & Positif dan Signifikan \\
\hline
\end{tabular}

Sumber:Data diolah, 2019

menunjukkan bahwa tenaga kerja berpengaruh positif dan signifikan terhadap produksi. Modal dengan nilai sig $0,021<0,05$ dan beta 0,384 menunjukkan bahwa modal berpengaruh postif dan signifikan terhadap produksi.

Pengujian persamaan 1 dilakukan untuk melihat pengaruh tenaga kerja dan modal terhadap produksi secara langsung yang dilakukan dengan menggunakan program SPSS Versi 20.0 maka uji regresi disajikan dalam Tabel 9.

Berdasarkan Tabel 9 tenaga kerja dengan nilai sig $0,045<0,05$ dan beta 0,325 menunjukkan bahwa tenaga kerja berpengaruh positif dan signifikan terhadap pendapatan. Modal dengan nilai sig 0,032 $<0,05$ dan beta 0,318 menunjukkan bahwa modal berpengaruh positif dan signifikan terhadap pendapatan. Produksi dengan nilai sig 0,016 $<0,05$ dan beta 0,350 menunjukkan produksi berpengaruh positif dan signifikan terhadap pendapatan.

Keterangan:

$\mathrm{X} 1$ = Tenaga Kerja

$\mathrm{X} 2=$ Modal
$\mathrm{Y} 1=$ Produksi

$\mathrm{Y} 2=$ Pendapatan

Untuk mengetahui nilai $e_{1}$ yang menunjukan jumlah variance produksi yang tidak dijelaskan oleh variabel-variabel tenaga kerja dan modal dapat dihitung dengan rumus. $\mathrm{e}_{1}=\sqrt{\left(1-\mathrm{R}_{\mathrm{i}}^{2}\right)}$

$$
\begin{aligned}
& =\sqrt{(1-0,948)} \\
& =\sqrt{0,052} \\
& =0,228
\end{aligned}
$$

Untuk mengetahui nilai $\mathrm{e}_{2}$ yang menunjukan variance pendapatan yang tidak dijelaskan oleh variabel tenaga kerja, modal dan produksi maka dihitung menggunakan rumus.

$$
\begin{aligned}
\mathrm{e}_{2} & =\sqrt{\left(1-\mathrm{R}_{\mathrm{I}}^{2}\right)} \\
& =\sqrt{(1-0,965)} \\
& =\sqrt{0,035} \\
& =0,187
\end{aligned}
$$

Untuk memeriksa validitas model, terdapat indikator untuk melakukan pemeriksaan, yaitu koefisien determinasi total hasilnya sebagai berikut:

$$
\begin{aligned}
\mathrm{R}_{\mathrm{m}}^{2} & =1-\left(\mathrm{Pe}_{1}\right)^{2}\left(\mathrm{Pe}_{2}\right)^{2} \\
& =1-(0,228)^{2}(0,187)^{2}
\end{aligned}
$$




$$
=0,982
$$

Keterangan:

$\mathrm{R}_{\mathrm{m}}^{2} \quad$ : Koefisien determinasi total

$\mathrm{e}_{1}, \mathrm{e}_{2}$ : Nilai kekeliruan taksiran standar

Berdasarkan hasil perhitungan koefisien determinasi total 0,982 maka, diperoleh bahwa keragaman data yang dapat dijelaskan oleh model adalah sebesar 98,2 persen atau dengan kata lain informasi yang terkandung dalam data sebesar 98,2 persen dapat dijelaskan oleh model, sedangkan sisanya yaitu 1,8 persen dijelaskan oleh variabel lain yang tidak terdapat dalam model yang di bentuk.

Berdasarkan dari persamaan regresi I dan persamaan regresi II serta nilai kekeliruan taksiran standar, maka dapat dibuat Diagram Jalur Penelitian pada Gambar 1.

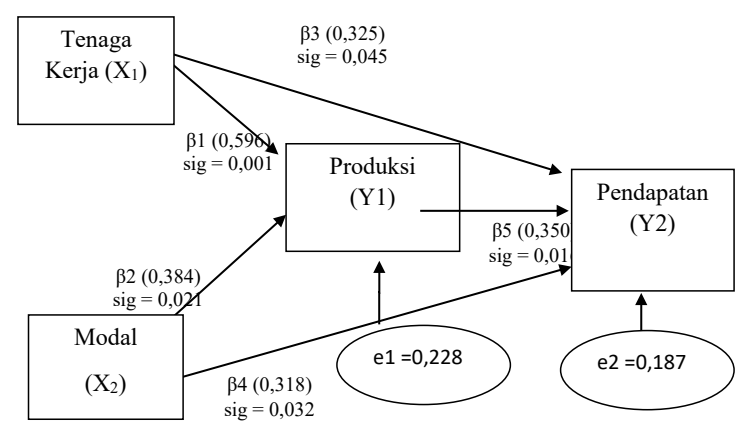

Gambar 1.

Diagram Hasil Analisis Jalur

$\mathrm{Y}_{1}=\beta_{1} \mathrm{X}_{1}+\beta_{2} \mathrm{X}_{2}+\mathrm{e}_{1}$

$\mathrm{Y}_{2}=\beta_{3} \mathrm{X}_{1}+\beta_{4} \mathrm{X}_{2}+\beta_{5} \mathrm{Y}_{1}+\mathrm{e}_{2}$

Keterangan:

$\mathrm{Y}_{1}=$ Produksi

$\mathrm{Y}_{2}=$ Pendapatan

$\mathrm{X}_{1}=$ Tenaga kerja

$\mathrm{X}_{2}=$ Modal

$\beta_{1} \ldots \beta_{5}=$ Koefisien regresi untuk masingmasing variabel $\mathrm{e}_{1}, \mathrm{e}_{2}=$ error

Berdasarkan uraian diatas Tabel 11 dapat diketahui nilai pengaruh langsung tenaga kerja terhadap produksi sebesar 0,596. Pengaruh langsung modal terhadap produksi sebesar 0,318 dan pengaruh langsung produksi terhadap pendapatan sebesar 0,350 . Pengaruh langsung tenaga kerja terhadap pendapatan sebesar 0,325. Pengaruh modal terhadap pendapatan sebesar 0,318. Pengaruh tidak langsung tenaga kerja terhadap pendapatan melalui produksi adalah sebesar 0,209. Nilai pengaruh tidak langsung modal terhadap pendapatan melalui produksi sebesar 0,134.

Jika $\mathrm{z}$ hitung $\leq 1,96$, maka $\mathrm{H}_{0}$ diterima yang berarti pendapatan asli daerah ( $\left.\mathrm{Y}_{1}\right)$ bukan variabel mediasi. Jika $\mathrm{z}$ hitung $>1,96$, maka $\mathrm{H}_{0}$ ditolak yang berarti pendapatan asli daerah (Y) merupakan variabel mediasi.

$$
\begin{aligned}
& \mathrm{S}_{\mathrm{b} 1 \mathrm{~b} 8}=\sqrt{ }\left(\mathrm{b} 7 \mathrm{~S}_{\mathrm{b} 1}^{2}+\mathrm{b}^{2} \mathrm{~S}^{2}{ }_{\mathrm{b} 7}\right) \\
& =\sqrt{ }(208,099)^{2}(252,837)^{2}+(948,895)^{2}(82,572)^{2} \\
& =\sqrt{ }(43.305,19)(63.926,55)+(900.401,72)(6.818,14) \\
& =\sqrt{ }(2.768 .351 .574,81+6.139 .060 .653,85) \\
& =94.379,08
\end{aligned}
$$

Keterangan:

$\mathrm{Sb}_{1}=$ Standar error koefisien regresi variabel $\mathrm{X}_{1}$ terhadap $\mathrm{Y}_{1}$

$\mathrm{Sb}_{7}=$ Standar error koefisien regresi variabel $\mathrm{Y}_{1}$ terhadap $\mathrm{Y}_{2}$

$$
\begin{aligned}
Z & =\frac{\text { b1b7 }}{\text { Sb1b7 }} \\
& =\frac{(948,895)(208,099)}{94.379,08} \\
& =2,09
\end{aligned}
$$

Keterangan:

$b_{1}=$ Koefisien regresi pengaruh variabel $X_{1}$ terhadap $\mathrm{Y}_{1}$

$\mathrm{b}_{7}=$ Koefisien regresi pengaruh variabel $\mathrm{Y}_{1}$

Tabel 11.

Hubungan Variabel Langsung dan Tidak Langsung Serta Pengaruh Total

\begin{tabular}{lccc}
\hline \multirow{2}{*}{ Hubungan Variabel } & \multicolumn{2}{c}{ Pengaruh } & \multirow{2}{*}{ Total } \\
\cline { 2 - 3 } & Langsung & Tidak Langsung & \\
\hline $\mathrm{X} 1 \rightarrow \mathrm{Y} 1$ & 0,596 & - & 0,596 \\
$\mathrm{X} 1 \rightarrow \mathrm{Y} 2$ & 0,325 & 0,209 & 0,534 \\
$\mathrm{X} 2 \rightarrow \mathrm{Y} 1$ & 0,384 & - & 0,384 \\
$\mathrm{X} 2 \rightarrow \mathrm{Y} 2$ & 0,318 & 0,134 & 0,454 \\
$\mathrm{Y} 1 \rightarrow \mathrm{Y} 2$ & 0,350 & - & 0,350 \\
\hline Sumber:Data diolah 2019 & & &
\end{tabular}


terhadap $\mathrm{Y}_{2}$

Berdasarkan hasil $\mathrm{z}$ hitung sebesar 2,09> 1,96 maka $\mathrm{H}_{0}$ ditolak dan $\mathrm{H}_{1}$ diterima. Artinya produksi $\left(\mathrm{Y}_{1}\right)$ sebagai variabel yang memediasi pengaruh tenaga kerja $\left(\mathrm{X}_{1}\right)$ terhadap pendapatan $\left(\mathrm{Y}_{2}\right)$.

Jika $\mathrm{z}$ hitung $\leq 1,96$, maka $\mathrm{H}_{0}$ diterima yang berarti pendapatan asli daerah $\left(\mathrm{Y}_{1}\right)$ bukan variabel mediasi. Jika $\mathrm{z}$ hitung $>1,96$, maka $\mathrm{H}_{0}$ ditolak yang berarti pendapatan asli daerah $\left(\mathrm{Y}_{1}\right)$ merupakan variabel mediasi.

$$
\begin{aligned}
\mathrm{S}_{\mathrm{b} 2 \mathrm{~b} 7} & =\sqrt{ }\left(\mathrm{b} 7^{2} \mathrm{~S}_{\mathrm{b} 2}^{2}+\mathrm{b} 2^{2} \mathrm{~S}_{\mathrm{b} 7}^{2}\right) \\
& =\sqrt{ }(208,099)^{2}(0,000)^{2}+(0,001)^{2}(82,572)^{2} \\
& =\sqrt{ }(43.305,19)(0,0)+(0,000001)(6.818,14) \\
& =\sqrt{ }(0,0+0,00681814) \\
& =94.379,08
\end{aligned}
$$

Keterangan:

$\mathrm{Sb}_{2}=$ Standar error koefisien regresi variabel $\mathrm{X}_{2}$ terhadap $\mathrm{Y}_{1}$

$\mathrm{Sb}_{7}=$ Standar error koefisien regresi variabel $\mathrm{Y}_{1}$ terhadap $\mathrm{Y}_{2}$

$$
\begin{aligned}
Z & =\frac{\mathrm{b} 2 \mathrm{~b} 7}{\mathrm{Sb} 2 \mathrm{~b} 7} \\
& =\frac{(0,001)(208,099)}{0,08} \\
& =2,60
\end{aligned}
$$

Keterangan:

$\beta_{2}=$ Koefisien regresi pengaruh variabel $\mathrm{X}_{2}$ terhadap $\mathrm{Y}_{1}$

$\beta_{7}=$ Koefisien regresi pengaruh variabel $Y_{1}$ terhadap $\mathrm{Y}_{2}$

Berdasarkan hasil $\mathrm{z}$ hitung sebesar 2,60 > 1,96 maka $\mathrm{H}_{0}$ ditolak dan $\mathrm{H}_{1}$ diterima. produksi sebagai variabel yang memediasi pengaruh tingkat modal $\left(\mathrm{X}_{2}\right)$ terhadap pendapatan $\left(\mathrm{Y}_{2}\right)$.

Pengaruh langsung tenaga kerja terhadap produksi genteng di Kecamatan Kediri Kabupaten Tabanan

Berdasarkan hasil analisis yang telah dilakukan diperoleh nilai standardized coefficient beta sebesar 0,596 dan nilai signifikansi sebesar $0,001<0,05$. Hal ini berarti $\mathrm{H}_{0}$ ditolak dan $\mathrm{H}_{1}$ diterima. Dengan demikian dapat disimpulkan bahwa tenaga kerja berpengaruh positif dan signifikan terhadap produksi genteng di Kecamatan Kediri Kabupaten Tabanan. Ini berarti apabila jumlah tenaga kerja meningkat 1 orang, maka produksi genteng akan mengalami peningkatan sebesar 0,596 unit. Meningkatnya 1 jumlah tenaga kerja hanya meningkatkan 0,596 unit dinilai masih kurang optimal, ini disebabkan oleh beberapa tenaga kerja belum mampu menggunakan teknologi yang produksi yang efisien, agar proses dalam memproduksi genteng mengalami peningkatan yang optimal dengan meningkatnya jumlah tenaga kerja. Menurut Anom (2017) hubungan variabel input produksi dengan output (hasilproduksi) merupakan fungsi produksi. Tentunya produksi dapat dijalankan melaluifaktor sumberdaya alam, biaya produksi, manusia, dan skill (teknologi).

Bekerja dapat diartikan sebagai melakukan suatu kegiatan untuk menghasilkan atau membantu menghasilkan barang atau jasa dengan maksud untuk memperoleh penghasilan berupa uang dan atau barang, dalam kurun waktu tertentu. Dalam suatu perusahaan tenaga kerja merupakan salah satu faktor produksi yang penting. Tanpa adanya tenaga kerja proses produksi tidak akan bisa berjalan (Mantra, 2003:225). Hasil penelitian ini sesuai dengan Novitri (2015), menyatakan bahwa variabel jumlah tenaga kerja mempunyai pengaruh yang dominan terhadap hasil produksi pada industri kecil tempe di Kota Indramayu. Berarti tenaga kerja berpengaruh signifikan terhadap hasil produksi. Begitupun dengan Penelitian yang dilakukan oleh Pradnyani (2014), menyatakan bahwa tenaga kerja mempunyai pengaruh yang positif dan signifikan terhadap jumlah produksi pada usaha perkebunan kakao di Kecamatan Abiansemal Kabupaten Badung. Penelitian ini juga didukung oleh Rahayu (2014) lamanya bekerja seseorangakan mempengaruhi hasil produksi (output).

Pengaruh langsung modal terhadap produksi genteng di Kecamatan Kediri Kabupaten Tabanan

Berdasarkan hasil analisis yang telah dilakukan diperoleh nilai standardized coefficient beta sebesar 0,384 dan nilai signifikansi sebesar $0,021<0,05$. Hal ini berarti $\mathrm{H}_{0}$ ditolak dan $\mathrm{H}_{1}$ diterima. Dengan demikian dapat disimpulkan bahwa modal 
berpengaruh positif dan signifikan terhadap produksi genteng di Kecamatan Kediri Kabupaten Tabanan. Ini berarti apabila modal meningkat 1 rupiah, maka produksi genteng akan mengalami peningkatan sebesar 0,384 unit. Meningkatnya 1 rupiah modal yang dikeluarkan hanya mampu meningkatkan 0,384 unit ini disebabkan oleh, modal yaitu bahan baku yang sulit sampai mendatangkan dari luar kabupaten bahkan sampai luar pulau bali. Hal inilah merupakan salah satu faktor kurang efisiennya modal dalam meningkatkan produksi.

Modal kerja adalah produk atau kekayaan yang digunakan untuk melakukan proses produksi. Modal kerja pada hakikatnya merupakan jumlah yang terus menerus ada dalam menopang usaha yang menjembatani antara saat pengeluaran untuk memperoleh bahan, alat dan jasa untuk digunakan selama proses produksi sehingga memperoleh penerimaan penjualan (Ahmad, 2004:72).

Penelitian ini sesuai dengan hasil penelitian Cahya (2015), mengatakan semakin besar modal yang digunakan akan berpengaruh terhadap jumlah produksi yang dihasilkan, maka tingkat penggunaanproses yang diperlukan untuk produksi akan semakin banyak.

\section{Pengaruh langsung tenaga kerja terhadap pendapatan pengusaha industri genteng di Kecamatan Kediri Kabupaten Tabanan}

Berdasarkan hasil analisis yang telah dilakukan diperoleh nilai standardized coefficient beta sebesar 0,325 dan nilai signifikansi sebesar $0,045<0,05$. Hal ini berarti $\mathrm{H}_{0}$ ditolak dan $\mathrm{H}_{1}$ diterima. Dengan demikian dapat disimpulkan bahwa tenaga kerja berpengaruh positif dan signifikan terhadap pendapatan pengusaha industri genteng di Kecamatan Kediri Kabupaten Tabanan. Ini berarti apabila jumlah tenaga kerja meningkat 1 orang, maka pendapatan akan mengalami peningkatan sebesar 0,325 rupiah. Meningkatnya 1 orang jumlah tenaga kerja hanya mampu meningkatkan 0,325 rupiah ini disebabkan karena, tenaga kerja yang digunakan beberapa pengusaha hanya pada tenaga kerja pengrajin gentengnya saja tidak ada tenaga kerja dibagian pemasaran atau pun pengaturan keuangan lainnya.

Dalam memutuskan tentang berapa banyak pekerja yang dipekerjakan, tujuan perusahaan adalah memperoleh keuntungan yang tinggi sehingga perusahaan menuntut jumlah tenaga kerja untuk memaksimalkan keuntunganya(Abel, 2005).

Pengaruh langsung modal terhadap pendapatan pengusaha industri genteng di Kecamatan Kediri Kabupaten Tabanan

Berdasarkan hasil analisis yang telah dilakukan diperoleh nilai standardized coefficient beta sebesar 0,318 dan nilai signifikansi sebesar $0,032<0,05$. Hal ini berarti H0 ditolak dan H1 diterima. Dengan demikian dapat disimpulkan bahwa modal berpengaruh positif dan signifikan terhadap pendapatan pengusaha industri genteng di Kecamatan Kediri Kabupaten Tabanan. Ini berarti apabila modal meningkat 1 rupiah, maka pendapatan akan mengalami peningkatan sebesar 0,318 rupiah. Meningkatnya 1 rupiah modal hanya mampu meningkatkan pendapatan 0,318 dinilai masih kurang optimal. Ini dikarenakan adanya persaingan pasar yang ketat yang industri gentengnya tidak hanya berada di Kecamatan Kediri Kabupaten Tabanan saja melainkan seperti industri genteng yang berada di Surabaya dan berbagai tempat lainnya.

Modal perusahaan merupakan biaya tetap. Semakin besar modal perusahaan maka peluang memasuki industri semakin besar. Untuk mem $\neg$ peroleh keuntungan perusahaan akan memp $\neg$ roduksi dalam kapasitas yang besar(Kurniati, 2010).Hasil penelitian ini sesuai dengan penelitianYanutya (2013), menyatakan secara parsial modal berpengaruh positif dan signifikan terhadap terhadap pendapatan. Hal ini mengindikasikan semakin besar modal yang dimiliki maka akan semakin besar pendapatan yang akan diperoleh. Hal ini juga sejalan dengan hasil penelitian Adhiatma (2014), yang menyatakan modal secara parsial memiliki pengaruh yang signifikan terhadap pendapatan pedagang kayu glondong di Kelurahan Karangkebagusan Jepara.Modal yang dikeluarkan akan mempengaruhi besar pendapatan yang akan diterima (Maharani, 
2016).

Pengaruh langsung produksi terhadap pendapatan pengusaha industri genteng di Kecamatan Kediri Kabupaten Tabanan

Berdasarkan hasil analisis yang telah dilakukan diperoleh nilai standardized coefficient beta sebesar 0,350 dan nilai signifikansi sebesar 0,016 $<0,05$. Hal ini berarti $\mathrm{H}_{0}$ ditolak dan $\mathrm{H}_{1}$ diterima. Dengan demikian dapat disimpulkan bahwa produksi berpengaruh positif dan signifikan terhadap pendapatan pengusaha industri genteng di Kecamatan Kediri Kabupaten Tabanan. Ini berarti apabila produksi meningkat setiap 1 unit, maka akan meningkatkan pendapatan sebesar 0,350 rupiah. Meningkatnya 1 unit produksi yang mengakibatkan pendapatan hanya meningkat 0,350 rupiah dinilai kurang optimal ini disebabkan karena, masih sedikit pengusaha yang mampu memaksimalkan penjualan produksi gentengnya. Ini merupakan salah satu faktor yang menyebabkan kurang optimalnya pendapatan pengusaha industri genteng.

Menurut Sukirno (2000:87), setiap produksi yang terdapat dalamperekonomian dimiliki oleh perusahaan akan mempengaruhi pendapatan. Hasil penelitian ini sesuai dengan penelitian Arfiani (2013), menyatakanbertambahnya produksi yang dihasilkan, maka otomatis akan meningkatkan penjualan perusahaan dan dengan harga yang lebih dari pengeluaran perusahaan tersebut sehingga akan mempengaruhi meningkatnya pendapatan bagi perusahaan tersebut.

Pengaruh tidak langsung tenaga kerja terhadap pendapatan melalui produksi genteng di Kecamatan Kediri Kabupaten Tabanan

Hasil perhitungan didapatkan perbandingan $\mathrm{z}$ hitung sebesar 2,09. Berdasarkan hasil $\mathrm{z}$ hitung sebesar 2,09> 1,96 maka $\mathrm{H}_{0}$ ditolak dan $\mathrm{H}_{1}$ diterima. Artinya jumlah tenaga kerja berpengaruh secara tidak langsung dan signifikan terhadap pendapatan melalui produksi. Hal ini menunjukkan bahwa apabila jumlah tenaga kerja meningkat, maka akan meningkatkan produksi. Apabila produksi meningkat, maka akan meningkatan pendapatan pengusaha industri genteng di Kecamatan Kediri Kabupaten Tabanan.

Pengaruh tidak langsung modal terhadap pendapatan melalui produksi genteng di Kecamatan Kediri Kabupaten Tabanan Hasil perhitungan didapatkan perbandingan $\mathrm{z}$ hitung sebesar 2,60. Berdasarkan hasil $\mathrm{z}$ hitung sebesar 2,60 > 1,96 maka $\mathrm{H}_{0}$ ditolak dan $\mathrm{H}_{1}$ diterima. Artinya modal berpengaruh secara tidak langsung dan signifikan terhadap pendapatan melalui produksi. Hal ini menunjukkan bahwa jika modal meningkat, maka akan meningkatkan produksi. Apabila produksi meningkat, maka akan meningkatan pendapatan pengusaha industri genteng di Kecamatan Kediri Kabupaten Tabanan. Ini sesuai dengan pernyataan Revathy (2016), menyatakan modal yang merupakan salah satu faktor produksi akan menentukan produktivitas perusahaan yang berdampak terhadap pendapatan.

\section{SIMPULAN}

Tenaga kerja dan modal secara langsung berpengaruh positif dan signifikan terhadap produksi genteng di Kecamatan Kediri Kabupaten Tabanan. Tenaga kerja, modal dan produksi mempunyai pengaruh positif dan signifikan terhadap pendapatan pengusaha industri genteng di Kecamatan Kediri Kabupaten Tabanan. Tenaga kerja dan modal berpengaruh secara tidak langsung terhadap pendapatan pengusaha industri genteng melalui produksi industri genteng di Kecamatan kediri Kabupaten Tabanan.

Diharapkan pemerintah dan pengusaha dapat meningkatkan produksi melalui tenaga kerja lebih optimal lagi dengan cara, tenaga kerja diberikan penyuluhan dan pelatihan atas penggunaan metode yang efisien dalam meproduksi genteng melalui teknologi yang ada agar tenaga kerja dapat melakukan kegiatan produksi yang optimal.

Diharapkan pengusaha dapat menambah dan mengelola modalnya lebih efisien agar produksi genteng menjadi lebih efektif dengan cara, lebih menambahkan modalnya terhadap pembelian bahan baku 
yang cenderung sulit didapatkan untuk kegiatan produksi agar dapat meningkatkan produksi genteng tersebut.

Diharapkan kepada pengusaha dapat menambah dan meningkatkan kualitas sumber daya manusianya yaitu tenaga kerjanya dengan cara, pengusaha bisa menambah tenaga kerjanya tidak hanya dibidang produksi saja. Melainkan pengusaha bisa menambah tenaga kerja dibidang pemasaran dan juga dibidang pengelolan keuangan agar dapat meningkatkan pendapatan.

Diharapkan kepada pengusaha meningkatkan modalnya dalam mengelola industri genteng dengan cara, meningkatkan daya saing melalui menguatkan jenis genteng tradisional yang merupakan ciri khas tersebut dan meningkatkan kembali kualitas genteng tersebut misalnya dalam hal pewarnaan genteng tersebut. Ini agar genteng yang dihasilkan dapat bersaing lebih baik lagi pasaran yang mengakibatkan meningkatnya pendapatan.

Diharapkan kepada pengusaha untuk meningkatkan jumlah produksi dan meningkatkan penjualan genteng tersebut. Salah satu caranya yaitu melalui media ekonomi digital seperti halnya media sosial dan e-commerce yang telah ada, dengan begitu pendapatan pengusaha ini akan mengalami peningkatan yang optimal.

\section{REFERENSI}

Abel, Andrew B and Ben S. Bernanke. 2005. Macroeconomics. Fifth Edition. United States: Pearson Addison Wesley.

Adhiatma, Alfian Arif. 2015. Pengaruh Modal Awal, Lama Usaha, Dan Jam Kerja Terhadap Pendapatan Pedagang Kayu Glondong Di Kelurahan Karang Kebagusan Kabupaten Jepara. Tugas Akhir Semester. Universitas Dian Nuswantoro Semarang.

Agus Budiartha, I Kadek dan I Gede Trunajaya. 2013. Analisis Skala Ekonomis Pada Industri Batu Bata Di Desa Tulikup, Gianyar, Bali. Jurnal
Ekonomi Kuantitatif Terapan. 6(1). Hal. $55-61$.

Ahmad. 2004. Ekonomi. Bandung: Grafindo Media Pratama.

Aldida, Bella dan Purbayu Budi Santosa. 2013. Analisis Produksi dan Efisiensi Industri Kecil dan Menengah (IKM) Batik Tulis di Kota Semarang. Diponegoro Journal Of Economics, 2 (1). Hal. 1-10.

Anom Dewa Gede. 2017. Penentu Kesejahteraan Pengusaha Pemindangan diKabupaten Tabanan. Jurnal Ekonomi Kuantitatif Terapan. 10(1). hal. 85-93

Arfiani, Ni Putu. 2013. Analisis Pendapatan Pengerajin Perak di Desa Kamasan Kabupaten Klungkung. E-Jurnal EP Unud. 2(6) Hal. 294-305.

Ariessi, Nian Elly dan Made Suyana Utama. 2017. Pengaruh Modal, Tenaga Kerja Dan Modal Sosial Terhadap Produktivitas Petani Di Kecamatan Sukawati Kabupaten Gianyar. Piramida. 13(2). Hal. 97 - 107.

Badan Pusat Statistik Provinsi Bali. 2018. Produk Domestik Regional Bruto Menurut Lapangan Usaha 2013-2017. BPS Provinsi Bali.

Budiman. 2015. Analisis Pengaruh Tenaga Kerja, Bahan Baku, dan Teknologi Terhadap Nilai Produksi Pada Industri Percetakan di Provinsi Riau. Jom FEKON. 2(2). Hal. 1-10.

Cahya Ningsih, Ni Made dan I Gst Bagus Indrajaya. 2015. Pengaruh Modal dan Tingkat Upah Terhadap Nilai Produksi Serta Penyerapan Tenaga Kerja Pada Industri Kerajinan Perak. Jurnal Ekonomi Kuantitatif Terapan, 8 (1). Hal. 83-91. 
Dinas Perindustrian dan Perdagangan Provinsi Bali. 2018. Data Direktori IKM Provinsi Bali Tahun 2013-2017. Denpasar. 2018 Kementrian Perindustrian Republik Indonesia Nomor 64/M-IND/PER/7/2016 Tentang Besaran Jumlah tenaga Kerja dan Nilai Investasi Untuk Klasifikasi Usaha Industri (diakses pada tanggal 4 agustus 2018).

Dinas Perindustrian dan Perdagangan Kabupaten Tabanan. 2017. Direktori Perusahaan Industri, Kabupaten Tabanan.

Firdausa, R. A., dan Fitrie. A. 2013. Pengaruh Modal Awal, Lama Usaha DanJam Kerja Terhadap Pendapatan Pedagang Kios Di Pasar Bintoro Demak. Diponegoro Journal of Economics, 2(1). Hal. 1-10.

Gupta, Umesh Kumar. 2016. An Analysis For The Cobb-Douglas Production Function in General Form. International Journal of Applied Research, 2 (4). pp. 96-99.

Huazhang . 2014. Agricultural Input and Output in Juangsu Province with Case Analyisys. Journal of Agricultural Science \& Technology, 15(11), pp: 2006-2010.

Ho, Thong Quoc, John F. Yanagida, and Prabodh Illukpitiya. 2014. Factors affecting Technical Efficiency of Smallholder coffe Farming in the Krong Ana watershed, Vietnam. Asian Journal of Agricultural Extension, economic \& Sociology. 3(1). Pp. 37-49.

Indra, I Gusti Agung Rahardi Bagus dan Luh Putu Aswitari. 2015. Analisis Skala Ekonomis Pada Industri Kerajinan Tas Kulit di Kota Denpasar. E-Jurnal
Ekonomi Pembangunan Universitas Udayana, 4 (12). Hal. 1445-1461.

Kurniati, Y. 2010. Dinamika Industri Manufaktur dan Respon terhadap Siklus Bisnis. Jakarta : Erlangga.

Kurniawan, Jarot. 2016. Dilema Pendidikan dan Pendapatan di Kabupaten Grobogan. Jurnal Ekonomi Kuantitatif Terapan. 9(1). Hal. 59 - 67.

Maharani Putri, Dwidan I Made Jember. 2016. Pengaruh Modal Sendiri dan Lokasi Usaha Terhadap Pendapatan Usaha Mikro Kecil Menengah (UMKM) di Kabupaten Tabanan (Modal Pinjaman sebagai Variabel Intervening). Jurnal Ekonomi KuantitatifTerapan.9(2).Hal. 142-150.

Mankiw, N Gregory Mankiw, Euston Quah and Peter Wilson. (Barlev Nicodemus Hutugalung, Penerjemah). 2011. Pengantar Ekonomi Mikro : Prinsip Ekonomi. Edisi Asia. Jakarta: Salemba Empat.

Mantra, Ida Bagus. 2003. Demografi Umum. Edisi ke 2. Yogyakarta: Pustaka

Marbek, I Nengah dan Ni Luh Karmini. 2013. Faktor - Faktor Yang Berpengaruh Terhadap Pendapatan Pekerja Pada Industri Genteng Di Desa Nyitdah Kecamatan Kediri Kabupaten Tabanan. E-jurnal EP Unud, 2 (6) : 325-333.

Nanga, Muana. 2005. Makro Ekonomi: Teori, Masalah, dan Kebijakan, Jakarta: PT Grafindo Persada.s

Novitri, Irma Amalia. 2015. Pengaruh Tenaga Kerja Dan Bahan Baku Terhadap Peningkatan Hasil Produksi Pada Industri Tempe (Studi Kasus di Desa Bojongsari Kabupaten Indramayu). Skripsi. Fakultas Syariah Institut Agama Islam Negeri (IAIN) Syekh 
Nurjati Cirebon, Jawa Barat.

Ng'ombe, J., Kalinda, T., Tembo, G., \& Kuntashula, E. 2014. Econometric Analysis of the Factors that Affect Adoption of Conervation Farming Practices by Smallholder Farmers in Zambia. Journal of Sustainable development. 7(4). Pp. 124-138.

Obioma, Bennett Kenechukwu and Anyanwu Uchenna N. 2015. The Efect of Industrial Development on Economic Growth (An Empirical Evidence In Nigeria 1973-2013). European Journal of Business and Social Sciences, 4 (2). pp. 127-140.

Ofuri, George. 2006. Contruction Industry and Economic Growth in Singapore. Bulletin Of Indonesia Economic Studies. 6(1). Pp. 57-70.

Ovtchinnikov, A.V. 2010. Capital structure decisions: Evidence from deregulated industries, Journal of Financial Economics, 95, pp. 249-274.

Prasetyo, Didik dan I Nengah Kartika. 2017. Analisis Faktor-Faktor Yang Mempengaruhi Produksi Ayam Broiler Di Kecamatan Marga, Kabupaten Tabanan. Fakultas Ekonomi dan Bisnis Universitas Udayana. Piramida. 13(2). Hal. $77-86$.

Pradnyani, Cok Istri Andari Sukma dan I Gusti Bagus Indrajaya. 2014. Analisis Skala Ekonomi dan Efisiensi Pada Usaha Perkebunan Kakao di Kecamatan Abiansemal Kabupaten Badung. E-Jurnal Ekonomi Pembangunan Universitas Udayana, 3(9): h:403-412.

Rahayu, Shabrina Umi dan Ni Made Tisnawati. 2014. Analisis Pendapatan Keluarga Wanita Single Parents (Studi Kasus Kelurahan Sesetan, Kecamatan
Denpasar Selatan Kota Denpasar). Jurnal Ekonomi Kuantitatif Terapan. 7 (2):189

Rimbawan, Nyoman Dayuh. 2012. Pertumbuhan Ekonomi Dan Kegiatan Ekonomi Angkatan Kerja Di Provinsi Bali. Piramida, 6(2):1918-1923.

Ramstetter, Eric D and Dionisius Narjoko. 2014. Ownership and Energy Efficiencyin Indonesian Manufacturing. Journal Bulletin of Indonesian Economic Studies, 50 (2): 255-276.

Revathy, S. and V. Santhi. 2016. Impact Of Capital Structure On Profitability Of Manufacturing Companiwes In India. International Journal of Advanced Engineering Technology. 7(1), pp: 24-28.

Rahmaddi, Rudy dan Masaru Ichihashi. 2013. The role of foreign direct investment in Indonesia's manufacturing exports. Bulletin of Indonesian Economic Studies. 49(3). Pp. 329-354.

Shanmugasundaram, S dan N. Panchanatham. 2011. Embracing Manpower for Productivity in Apparel Industry. International Journal of Innovation, management and Technology, 2 (3). pp. 232-237.

Sukirno, Sadono. 2000. Teori Mikro Ekonomi. Jakarta: Raja Grafndo Persada.

2012. Mikro Ekonomi Teori Pengantar Edisi Ketiga. Jakarta: Raja Grafndo Persada.

Sulistiana, Septi Dwi. 2013. Pengaruh Jumlah Tenaga Kerja dan Modal Terhadap Hasil Produksi Industri Kecil Sepatu dan Sandal di Desa Sambarito Kecamatan Sooko kabupaten Mojokerto. Jurnal Ekonomi 
Pembangunan Fakultas Ekonomi Universitas Negeri Surabaya. 1(3). Hal. 1-18.

Sumarsono, Sonny. 2009. Teori dan Kebijakan Publik Ekonomi Sumber Daya Manusia. Yogyakarta : Graha Ilmu.

Sopingi, Agus Suman, Soemarno, and Bagyo Yanuwiadi. 2015. Efficiency Analysis in Small Industry of Tiles and Bricks Production (Case Study in Nganjuk District). World Environment, 5(1). pp. 39-45

Tambunan, Tulus. 2002. Usaha Kecil dan Menengah di Indonesia, Beberapa Issu Penting. Jakarta: Salemba Empat.

Widodo, Wahyu. 2014. Ekonomi Aglomerasi, Firm-level Efisiensi, dan Produktivitas Pertumbuhan (Bukti empiris dari Indonesia). Bulletin Of Indonesian Economic Studies (BIES). 50(2). Pp: 291-292.

Wijaya, I.B Kresna dan Made Utama. 2016. Analisis Faktor-Faktor Yang Mempengaruhi Pendapatan Industri
Kerajinan Bambu di Kabupaten Bangli. E-Jurnal Ekonomi Pembangunan Universitas Udayana, 5 (4). hal. 434-459.

Wulandari, Arthina, Djinar Setiawina dan Djayastra. 2016. Analisis FatorFaktor yang Mempengaruhi Produksi Industri Perhiasan Logam Mulia di Kota Denpasar. E-Jurnal Ekonomi dan Bisnis Unud, 6 (1). Hal. 79-108.

Yanutya, Pukuh Ariga Tri. 2013. Analisis Pendapatan Petani Tebu Di Kecamatan Jepon Kabupaten Blora.Economics Development Analysis Journal Fakultas Ekonomi. Univesitas Negeri Semarang. 2(3). Hal. 286-296.

Youriyah, Enny. 2007.Pengaruh Modal, Tenaga Kerja, dan Lama Usaha Terhadap Pendapatan Pengusaha Tempe Kedelai di Desa Jatiguwi Kecamatan Sumberpucung Kabupaten Malang. Skripsi Fakultas Ekonomi Universitas Jember. 